MATEC Web of Conferences 46, 05001 (2016)

DOI: $10.1051 /$ matecconf $/ 20164605001$

(C) Owned by the authors, published by EDP Sciences, 2016

\title{
Fire risk related to the use of PV systems in building facades
}

\author{
Lamberto Mazziotti ${ }^{1}$, Piergiacomo Cancelliere ${ }^{1}$, Giuseppe Paduano ${ }^{1}$, Paolo Setti ${ }^{2}$ and Samuele Sassi ${ }^{2}$ \\ ${ }^{1}$ Ministry of Interior Italian National Fire Services Largo Santa Barbara 2, Rome, Italy \\ ${ }^{2}$ FSC ENGINEERING SRL, Fire \& Structure Consulting, via A. Zenon 4, Milano, Italy
}

\begin{abstract}
Nowadays the use of photovoltaic (PV) systems in buildings is not only related to the solar energy conversion into electrical one, but these PV modules or panels could also be used with aesthetic features or, even more, as thermal protection systems in building facades.

Thanks to the technical development of the photovoltaic industry, PV system can easily be architectonically integrated into building construction elements such as roofs, vertical façade components, both with opaque or transparent surfaces. Furthermore, PV construction facades elements could also be provided by openings like doors or windows.

Accident analysis show that the use of PV systems as construction elements could increase the risk of fire in buildings. In fact, international and National data report a growing number of fire caused by PV system applied or integrated in buildings. The Italian National Fire Service, that is the Authority having jurisdiction for fire safety in buildings (in Italy), in 2012 has released a Guideline in order to asses and mitigate the risk of fire when a PV system is put in place on a building as a façade or as a roof. The Guideline addresses not only the reduction of the PV fire ignitions causes and the aspects related to the fire spread due to the combustible parts that constitute PV modules or panels, but also take into account the safety of both the maintenance personnel and the rescue teams.

This paper focuses on the fire safety aspects related to the use of fire PV panels and systems in building facades, showing some interesting experimental data related to the fire behaviour of these components and underlining the factors that promote the spread of fire, like the high operating temperature of the PV system itself.
\end{abstract}

\section{INTRODUCTION}

Photovoltaic (PV) Systems exploit the photovoltaic effect to convert the solar radiation into electrical energy. Environmental incentive policies worldwide are supporting the use of solar PV electrical energy converters. Over the last decade, even during difficult periods of industry consolidation and economic crises, a considerable increase in PV plant installations has been recorded. In fact, the global PV market has marked a record growth in 2011, relenting in 2012 and growing again in 2013. In 2013 alone, PV plants have produced at least $38.4 \mathrm{GW}$ of newly-added capacity, and almost $11 \mathrm{GW}$ only in Europe, reaching more than $138 \mathrm{GW}$ of installed electrical power around the globe [1].

PV systems for buildings are designed and built not only to perform the function of electric energy production, but also to be put in place as construction elements in order to protect the building by the

This is an Open Access article distributed under the terms of the Creative Commons Attribution License 2.0, which permits unrestricted use, distribution, and reproduction in any medium, provided the original work is properly cited. 


\section{MATEC Web of Conferences}

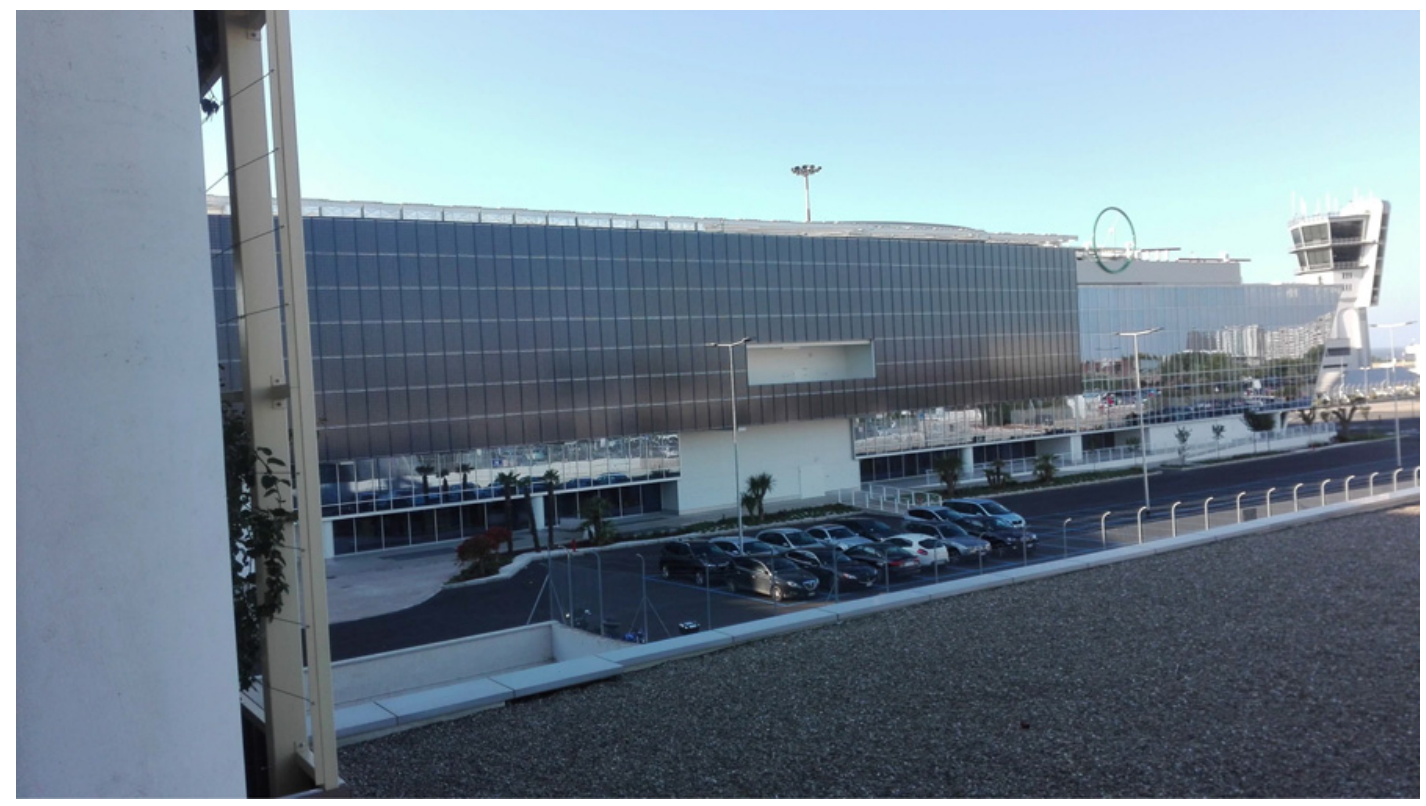

Figure 1. PV façade of the airport terminal of Bari Palese (Italy).

action of water, snow, mechanical shocks or to meet requirements related to the energy classification of the building and the thermal comfort.

The PVs offer enormous potential for designers of buildings, but they must however be watched very carefully in terms of fire risk.

PVs can influence the building's orientation, footprint, layout and form; they will affect the building fabric and will be an important element of the environmental and building systems. They need to be considered as an integral part of the energy strategy of the building and of its functioning. The integration of PVs with the other building elements is critical to success and appearance and aesthetics are, as ever, especially important. The PV building products today can be important constructive elements of the building construction envelopes, and often they are part of its facades.

Much PV claddings can be considered to be panes of glass to which PV cells are applied and so the extensive experience of glazed facades can be built upon. In addition, modules can be easily incorporated into other proven systems such as rain-screen cladding.

Curtain walling systems are a well-established technology used in numerous prestige projects such as city centre offices. The mullion/transom stick system is the most common. Vision areas are normally double-glazed and non-vision areas are either opaque glass or insulated metal panels. PV modules can be incorporated easily as factory-assembled double-glazed units. The outer pane might be laminated glass on which in applied PV-resin glass; then we have the inner pane (glass). A sealed air gap is also placed between the two glasses. The overall thickness of the module would typically be under $30 \mathrm{~mm}$. As an example, next figure reports a PV façade of the airport terminal of Bari Palese (Italy).

Since the first objective of the energy conversion systems is efficiency, the design and installation of PV systems focus mainly on efficiency aspects in order to exploit the maximum amount of the solar irradiance. Therefore, the fire risk due to an installation of a photovoltaic system is generally not well addressed. According to a recent survey of the National Fire Brigade (Italy), around 1600 fire-related accidents have occurred in the nearly 560,000 PV plants currently installed in Italy. Some severe fires involving buildings with PV systems have lately occurred in many European countries and in the USA. Even though PV solar energy converters are not the cause of ignition, in case of an outbreak of a fire in 
hosting buildings, they will enhance fire spread and trigger flame propagation mechanisms. Hence, fire safety issues of a photovoltaic solar energy converter must be addressed both as a cause and as a victim of a fire. In fact they may be causing the fire that suffer it and contribute to its propagation.

The article opens with a section where the main causes and faulty mechanisms of PV fire ignition are illustrated, and continues with a section dedicates to the PV fire safety guideline issued by the Italian National Fire Services. The third section deals with the importance of testing procedures for the fire rating characterization of PV modules.

\section{PV MAIN CAUSES AND MECHANISMS OF FIRE IGNITION}

Experimental data demonstrated that special attention should be paid to the technological aspects of PV systems and, above all, to the possible reduction of some critical production defects, that should be avoided in order to reduce the risk of fire in buildings.

Since PV electrical plants are a subset of the family of electrical plants, they show the two main causes of electrical fire ignition: overload and short circuit. Moreover, if a PV electrical plant is designed and put in place according to national, European or international electrical code recommendations (i.e., NFPA 70, IEC 60364-7-712, CEI 64-8) the fire risk due to overload and short circuit is well addressed and mitigated. Furthermore, PV cell outputs characteristics shows a short circuit current a little greater than the nominal one.

Unfortunately, PV power plants show a set of proper causes of electrical fire ignition. There are two major considerations for fire safety of photovoltaic systems [2]: Fires could be caused by PV components and systems - "origin fire scenario"; Fires could be caused by external sources - "victim fire scenario".

Arcing (Series Arcing, Parallel Arcing, Grounding Arcing) is one of the main causes of fire ignition [3]. Another important cause of fire ignition is related to the mechanism called in literature as "hot spot" [4]. An Hot spot on a PV module produces localized heating on the back sheet that could ignite and start a proper fire. Flowing of reverse currents in a module due to shadows or PV cell misalignment is responsible for the mechanism of fire ignition called "mismatch" [5]. Lack or bad connection among modules, strings (a series connection of two or more modules) and inverter could generate an enough amount of heat energy that could start a fire (as represented in Fig. 2).

Furthermore, during a PV fire event it is not possible to turn off the whole power system in order to guarantee that all the components are de-energized, while PV module and panels are exposed to solar or artificial light [6]. Whenever sufficient voltage is developed by a number of PV modules in series, there is a risk of electric shocks. Higher direct current (DC) voltage may be used in PV systems because it can lead to reduced wiring size and higher inverter efficiency. Hence, electrical hazards to firefighters involved in the mitigation of a fire concerning photovoltaic modules [7] ought to be also considered and addressed in a PV building.

\section{THE PV FIRE SAFETY GUIDELINE}

The presence of photovoltaic systems on buildings, both applied (BIPV) and integrated (BIPV), could worsen the existing level of risk of fire because the photovoltaic modules, panels and components could contribute significantly to the spread of fire outside or through the construction, interferes with smoke and vent system of the combustion products, obstacles to the operations of firefighting and introduce an additional danger for electric shock to the firefighters and rescue workers to the presence of elements of the circuit energized.

The Italian National Fire Services have issued a Guideline [8], [9] and [10] with the aim to reduce the outbreak of a PV fire related incident and their consequences on host buildings and construction works. The guideline has been developed with a non-prescriptive approach; in fact, according to the Regulation of the Construction Product - CPR Regulation [11] (EU) n.305/2011 of 9 March 2011, the 


\section{MATEC Web of Conferences}

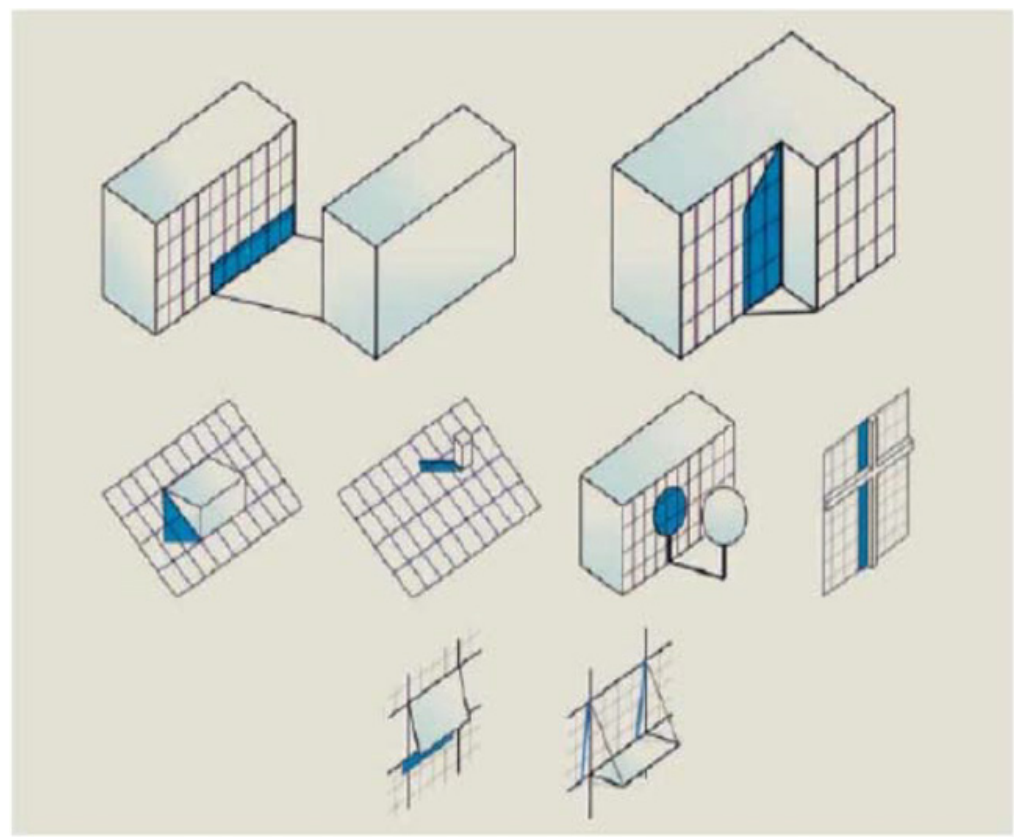

Figure 2. PV Self-shading failure mechanisms.

assessment and mitigation of the fire risk as a result of a PV plant installation on a building should be performed in order to meet the basic requirement n. 2 of construction work: "Safety in case of fire". The basic requirement n. 2 - Safety in case of fire - claims that a construction work must be designed and built in such a way that in the event of an outbreak of a fire,

(1) The load-bearing capacity of the construction can be assumed for a specific period of time;

(2) The generation and spread of fire and smoke within the construction works are limited;

(3) The spread of fire to neighbouring construction work is limited;

(4) Occupants can leave the construction work or be rescued by other means;

(5) The safety of rescue teams is taken into consideration.

The design and the installation of a PV power plant must be carried out in order to meet the basic requirement n. 2 listed above, addressing the following issues:

1. Avoiding interference with the ventilation system of the combustion products, obstruction of skylights and impediment of natural smoke and heat exhaust ventilators;

2. Avoiding the spread of an outbreak fire from the photovoltaic generator to the building and /or between its compartments in which its incorporated;

3. Evaluating the influence on the fire spread due to PV cables, switchboards and modules on the roof and or the façade of the host building/construction work;

4. Safety of maintenance personnel

5. Safety of the rescue team.

A complete analysis and discussion of the Italian Guideline for the fire safety of PV Systems applied or integrated in buildings is reported in [12].

One of the main fire safety goal for a building design is to restrict the vertical fire spread so that the smoke and flames are limited to the fire origin floor. The new building façade and curtain wall topologies 
could overwhelms concerns for fire safety, therefore the Italian National fire service has released a Fire Code Guideline in order to address the fire safety design for an high rise building façade [13].

As well known, the most used façades are built whit a series of layers of materials that increase insulating and sound absorbing performances without any considerations of combustibility and participation to fire tendency. For this reason, often, an ignition of a façade becomes a severe problem for the protection of people and property. Furthermore, if a fire starts at road level -i.e. a burning car or a waste container -, and ignite a nearby building façade covered or completely built up by combustible materials, taking into account the vertical position of the fuel and the unlimited presence of oxidizer quantity (the oxygen in the atmosphere), the fire façade could become a real huge torch. In order to reduce the vulnerability of the overall cover building system, the lightweight, high insulation and sound absorbing materials, and also PV cladding and covers used in the construction of a facade must have a proper reaction to fire performance. The next section reports the fire rating characterisations of PV module and panels used as applied or integrated system in building.

\section{FIRE RATING OF PV MODULES}

Fire spread and flame propagation on a roof or a building façade are strongly influenced by the Reactionto-Fire of roof and building products and materials. In fact, Reaction-to-Fire of a construction product deals with characteristics such as ignition, flame spread, heat release rate, smoke and gas production and the occurrence of burning droplets.

The fire rating of PV modules in the EU market is not mandatory; in fact when the PV module international standard IEC 61730-2 "Photovoltaic (PV) module safety qualification - Part 2: Requirements for testing" becomes the European standard EN 61730-2, the Fire Test MTS 23 could be performed only if requested by the manufacturer of the PV modules. The MTS 23 test is carried out according to the ANSI UL/790 standard ("Standard for Standard Test Methods for Fire Tests of Roof Coverings"), and the fire performance classification of PV module ranges from Class C - "fundamental fire rating" - , to Class B to Class A - "highest fire rating" - ; the standard also requires a minimum fire resistance rating of Class $\mathrm{C}$ for any building-mounted module. Furthermore, UL 790 Standard addresses two fire protection concerns: flame spread along the roof and fire penetration.

The EN 61730-2 standard also states that the MTS 23 test specifies fundamental requirements and may not be sufficient to satisfy the needs for a module intended for building applications according to local or national building fire code requirements.

Following the last sentence, the Italian National Fire Services, that is the Authority Having Jurisdiction for fire safety in Italy, according to the experimental activities carried out by the Passive Fire Protection Area of the Central Directorate for Fire Prevention and Technical Safety has issued a national Resolution in order to test and classify the Reaction to fire rating of PV modules.

Since the classification of the fire behaviour and the certification of materials for the purpose of fire prevention are regulated by the Decree of the Ministry of the Interior issued on June 26, 1984 [14], the PV Resolution states that a PV module can be classified following the Italian Reaction to fire Classification provided by the standards, test methods and classification procedures stated in the aforementioned Decree.

The national reaction-to-fire performance classifications for combustible materials are determined by using the results from a combination of the three tests shown below:

- UNI 9174, Reaction to fire of products subjected to a flame in the presence of radiant heat [15];

- UNI 8456, Combustible products which can be hit by flames on both surfaces - Small flame test [16];

- UNI 8457, Combustible products which can be hit by flames on one surface - Small flame test [17]; 
Table 1. Italian classification of reaction to fire for materials.

\begin{tabular}{|c|c|c|c|c|c|c|c|}
\hline Test Method & \multicolumn{6}{|c|}{ Test Results } & Reaction to fire \\
\hline UNI 9174 & \multirow{2}{*}{\multicolumn{6}{|c|}{$\begin{array}{l}\text { I Category } \\
\text { I Category }\end{array}$}} & 1 \\
\hline UNI 8457 & & & & & & & \\
\hline UNI 9174 & II Category & or I & & & & & 2 \\
\hline UNI 8457 & I Category & II & & & & & \\
\hline UNI 9174 & III Category & or II & or I & or II & & & 3 \\
\hline UNI 8457 & I Category & III & III & II & & & \\
\hline UNI 9174 & IV Category & or III & or III & or IV & or II & or I & 4 \\
\hline UNI 8457 & III Category & IV & III & II & IV & IV & \\
\hline UNI 9174 & \multirow{2}{*}{\multicolumn{6}{|c|}{$\begin{array}{l}\text { IV Category } \\
\text { IV Category }\end{array}$}} & 5 \\
\hline UNI 8457 & & & & & & & \\
\hline
\end{tabular}

Table 1 illustrates how the outputs results of each test are combined to produce the overall national classifications: combustible materials and products are divided into 5 categories, 1, 2, 3, 4 and 5, with 1 the best level of performance and 5 the worst. The table is derived from UNI 9177 "Reaction to fire combustible products classification" [18].

The UNI 8457 test applies a little ignition flame to the lower border of the specimen under test for 30 seconds, observing and measuring the flame propagation speed, the damaged zone of the specimen, the post glowing time and the flaming droplet/particles.

The UNI 9174 deals with the reaction to fire performance of products that can be hit by a flame and a radiant heating; the specimen under test is placed on an incombustible support exposed to a radiant panel and hit by a flame to the lower side of the specimen. During the test, the heat emitted by the radial panel is equal to $6,2 \mathrm{~W} / \mathrm{cm}^{2}$. During the radiant panel test, the following parameters are observed and recorded:

- ignition velocity;

- flame propagation speed;

- damaged zone extension;

- Post glowing time;

- Flaming droplet/particles.

Next figure shows some fire test result on a façade PV module during the test with a flame in the presence of radiant heat: the left image of the figure highlights the layer separation due to the PV backsheet combustion, while the centre of the figure shows the mechanics of PV backsheet blistering. The right part of the figure depicts the height of the flame during the PV combustion.

The class 1 reaction to fire rating according to the Italian test procedure illustrated above can be easily achieved for PV module that are "glass to glass" type. In the most common PV module technology, the glass is only used on the side exposed to sun, while the backsheet is generally constitute by combustible materials. The flame spread behavior as well as the flame speed propagation are strictly related to the materials chosen to built up a PV module backsheet. In order to comply to the Italian Reaction to Fire code requirements, a PV module manufacturer should asses the material chosen for building up a proper reaction to fire PV module. A detailed explanation of the Italian reaction to fire method applied to PV module characterisation is reported in [19].

\section{PV MODULE AS CONSTRUCTION PRODUCTS}

In construction terms, Building integrated PV systems should play the same role as the traditional wall and roofing cladding elements they replace. Consequently, they must address all the normal issues of a 

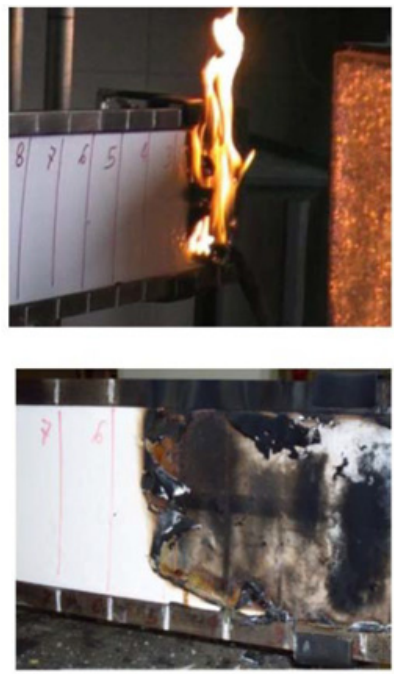

Backsheet layer separation
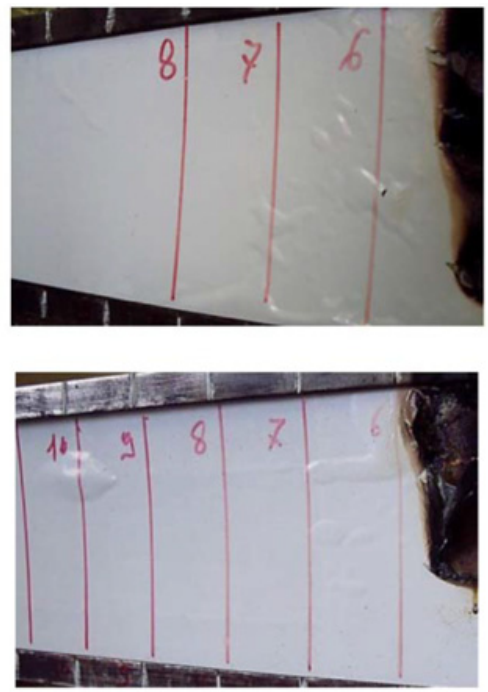

Backsheet blistering
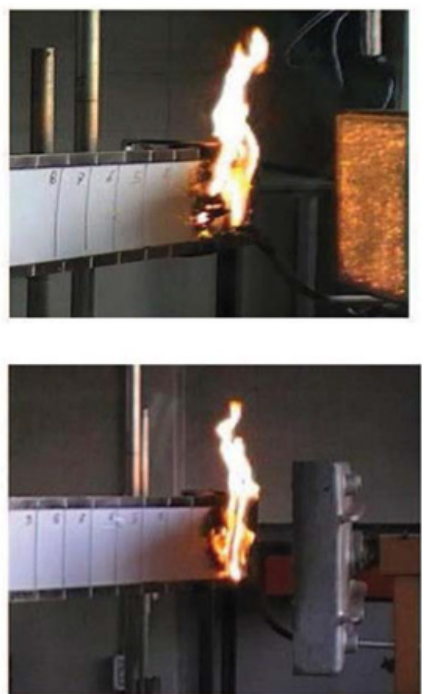

Flame height

Figure 3. Façade PV module subjected to Italian radiant panel reaction to fire test.

construction product, i.e. appearance, weather tightness and protection from the elements, wind loading, lifetime of materials and risks and consequences of failure and all the safety aspect (construction, fire, electrical, etc.).

PV modules and systems are not yet regulated by any European harmonized standard. There is an European project performed by a working group and recently submitted to CEN ad CENELEC entitled as "prEN 50583 Photovoltaics in Buildings:2012" [20]. This prEN introduces for the first time the definition of the terms BIPV and BAPV.

BIPV are Building Integrated Photovoltaic modules providing a function as defined in the European Construction Product Directive CPD 89/106/CE [11]. Therefore, a PV module can be considered as a BIPV if it take parts for the integrity of the building's functionality. In other words, if an integrated PV module is dismounted, it would have to be replaced by an appropriate building component. This means that the BIPV modules must be able to perform on or more of the following functions:

- mechanical rigidity and structural integrity;

- primary weather impact protection: rain, snow, wind, hail;

- energy economy, such as shading, daylighting, thermal isulation;

- fire protection;

- noise protection.

BAPV are considered Building Attached photovoltaic, if the PV modules are mounted on a building envelope and do not fulfil the above criteria for building integration. This means that the integrity of the building functionality is independent of the existence of a building-attached photovoltaic module.

Furthermore, the European draft standard introduces several application categories and subdivides these into the essential requirements of the European Construction Product Directive. Façade elements fall into Category $\mathrm{C}$ and Category $\mathrm{D}$ as reported in Fig. 4.

The prEN 50583 assigns application - specific requirements to PV modules - divided into the main categories "containing" and "not containing glass panes". 


\begin{tabular}{|l|l|}
\hline Category C: & $\begin{array}{l}\text { Non-sloped (vertically) mounted not accessible } \\
\text { from within the building }\end{array}$ \\
\hline & $\begin{array}{l}\text { The PV modules are mounted in the building } \\
\text { envelope at an angle between and including both } 75^{\circ} \\
\text { and } 90^{\circ} \text { (see Fig. 1) with a barrier behind preventing } \\
\text { large pieces of glass or persons falling to an adjacent } \\
\text { lower area inside the building }\end{array}$ \\
\hline Category D: & $\begin{array}{l}\text { Non-sloped (vertically) mounted accessible from } \\
\text { within the building }\end{array}$ \\
\hline & $\begin{array}{l}\text { The PV modules are mounted in the building } \\
\text { envelope at an angle of between and including both } \\
75^{\circ} \text { and } 90^{\circ} \text { (see Fig. 1) }\end{array}$ \\
\hline
\end{tabular}

Figure 4. PV Façade elements application categories according to prEN 50583 "Photovoltaic in Buildings".

For the safety in case of fire, the general requirements for all BIPV categories refers to the EN 13501-1 standard, having a minimum requirement of European reaction to fire class E. For Category C façade PV elements fire classification standard should be performed according to EN 13501-2 and EN 13501-5, while Category D requires only EN 13501-2 Fire classification. For PV flexible plastic and rubber sheets, the fire performance could require Broof T1, T2, T3 or T4 classification according to EN TS 1187:2012.

\section{CONCLUSION}

Safety is a prime concern for the photovoltaics (PV) industry. As a technology deployed on residential and commercial buildings, it is critical that PV not cause damage to the buildings nor harm the occupants. The issue of an European harmonised standard could be useful for making façade PV modules inherently safer especially against fire risk.

The main conclusion is that the reduction of fire risk, fire spread and proper ignition mechanisms caused by such systems are strongly related to a proper and accurate risk assessment of the PV building installations and to the testing, qualification and certification aspects of the fire behaviour of the PV façade elements. Combining safer PV modules with better system designs can solve many of the safety problems observed with today's façade PV systems.

\section{References}

[1] EPIA (2014-2018) Global market outlook for photovoltaic. www.epia.org/news/publications/ global-market-outlook-for-photovoltaics-2014-2018/].

[2] Zhao Y, de Palma J, Mosesian J, Lyons R, Lehman B. Line-Line Fault Analysis and Protection Challenges in Solar Photovoltaic Arrays. IEEE Transactions On Industrial Electronics 2013; 60(9). DOI: 10.1109/TIE.2012.2205355.

[3] International Photovoltaic Reliability Workshop II PV Fire: Experience and Studies Experience Studies Liang Ji Underwriters Laboratories Inc (UL) July 31, 2009 T A i Copyright@ 1995-2007 Underwriters Laboratories Inc. Tempe, Arizona, USA.

[4] Qiu YN. Electrical mismatch within single junction amorphous silicon and micromorph tandem thin film PV modules, 34th IEEE Photovoltaic Specialists Conference (PVSC), 2009 7-12 June 2009]. 
[5] Spertino F, Akilimali JS. Are manufacturing I-V mismatch and reverse currents key factors in large photovoltaic arrays. IEEE Transactions on Industrial Electronics 2009; 56(11):4520-4531.

[6] Behavior of the Electrical Parameters of PV Modules Subject to a Flame Ignition, P. Cancelliere, V. Puccia, G. Longobardo, C. Liciotti, M. Cardinali, 28th European Photovoltaic Solar Energy Conference and Exhibition Session.

[7] Risk of electrocution during fire suppression activities involving photovoltaic systems, Riccardo Tommasini, Enrico Pons, Federica Palamara, Calogero Turturici, Pietro Colella - Fire Safety Journal, 67, July 2014, Pages 35-41.

[8] Note n. 1324 February 7, 2012 "Guideline for PV plant installations", 2012 Edition ("Guida per l'installazione degli impianti fotovoltaici Edizione", Anno 2012).

[9] Note. n. 6334 May 4, 2012 - Explanation to the requirements of the Note n. 1324 February 7, 2012 (in Italian).

[10] Note PROTEM 622/867 February 18, 2011 "Procedures in case of intervention in the presence of photovoltaic panels - firefighters safety" (in Italian).

[11] REGULATION (EU) No 305/2011 OF THE EUROPEAN PARLIAMENT AND OF THE COUNCIL. Laying down harmonised conditions for the marketing of construction products and repealing Council Directive 89/106,EEC. Official Journal of the European Union 2011; L88/5, 54, 4 April 2011.

[12] PV electrical plants fire risk assessment and mitigation according to the Italian national fire services guidelines, Piergiacomo Cancelliere, FIRE AND MATERIALS Article first published online: 5 DEC 2014, DOI: 10.1002/fam.2290.

[13] The Italian National Guidelines for the fire safety of facades, Mazziotti Lamberto and Piergiacomo Cancelliere, 1st International Seminar for Fire Safety of Facades Paris, France, November 14-15, 2013 Published online: 29 November 2013, DOI: http://dx.doi.org/ $10.1051 /$ matecconf $/ 20130901005$.

[14] Decree of the Ministry of the Interior June 26, 1984 "Classification of reaction to fire and approval of materials for the fire prevention" (in Italian).

[15] UNI 9174, Reaction to fire of products subjected to a flame in the presence of radiant heat.

[16] UNI 8456, Combustible products which can be hit by flames on both surfaces - Small flame test.

[17] UNI 8457, Combustible products which can be hit by flames on one surface - Small flame test.

[18] UNI 9177 " Reaction to fire - combustible products classification".

[19] Fire Behaviour and Performance of Photovoltaic Module Backsheets, Piergiacomo Cancelliere, Claudio Liciotti, Fire Technology pp 1-16 First online: 11 June 2015.

[20] Testing and Standards for new BIPV products, Pellegrino, M.; ENEA (Agenzia Naz. per le Nuove Tecnol., l'Energia e lo Sviluppo Sostenibile), Portici, Italy; Flaminio, G.; Graditi, G., Industrial Electronics Society, IECON 2013 - 39th Annual Conference of the IEEE. 